\title{
INTRAOPERATIVE NEUROMONITORING DURING SURGICAL CORRECTION OF SPRENGEL'S DEFORMITY
}

\section{NEUROMONITORING ŚRÓDOPERACYJNY PODCZAS CHIRURGICZNEJ KOREKCJI DEFORMACJI SPRENGLA}

Agata Maria Kaczmarek ${ }^{1}$, Juliusz Huber ${ }^{1}$, Przemysław Daroszewski², Maciej Zbigniew Głowacki ${ }^{3}$, Agnieszka Szymankiewicz-Szukała' ${ }^{1}$, Anna Kalek ${ }^{1}$

'Poznan University of Medical Sciences, Department of Pathophysiology of Locomotor Organs, Poland

2Department of Organization and Management in Health Care, Wiktor Dega Orthopaedic and Rehabilitation Hospital, Poznan University of Medical Sciences, Poland

${ }^{3}$ Department of Pediatric Orthopedics and Traumatology, Poznan University of Medical Sciences, Poland

\section{ABSTRACT}

\section{Introduction}

Neuromonitoring (IOM) is a procedure for verification of the nerve impulse transmission along structures of central and peripheral nervous system during surgical procedures. Motor evoked potentials (MEPs) recordings from muscles induced with electrical pulses transcranially to motor cortex centers are especially useful during the surgery with an increased risk of iatrogenic damage to efferent nerve structures.

\section{Aim of the study}

The aim of this report is to present the scenario of the reversible inhibition in pathways transmitting nerve impulses during surgical correction of Sprengel's deformity with the assessment of IOM.

\section{Material and methods}

Nine-year old girl was admitted to the hospital due to congenital high scapula. Corrective surgery was performed using the Woodward technique with an assessment of IOM.

\section{Results}

The amplitudes and latencies of the MEPs from muscles of upper right extremity were recorded as decreased and increased, respectively at about $20 \%$ during the final fixation of scapula. Thanks to these recordings surgeons could prevent the permanent damage of the brachial plexus fibers, by partial releasing of applied sutures. After surgery and subsequent rehabilitation the patient returned to the normal activity in right upper extremity. Association of electromyography and MEPs results helped with ordering and controlling the course of treatment.

\section{Conclusions}

The benefit of IOM relay on the safety of orthopedic surgery and decreasing the number of iatrogenic perioperative complications. This diagnostic procedure is also a strong point for argumentation in hospital administration during negotiations with lawyer representing the patient when iatrogenic complication appear. 
Keywords: neuromonitoring, Sprengel's deformity, Woodward method

\section{STRESZCZENIE}

\section{Wstęp}

Neuromonitoring (IOM) to procedura weryfikacji przewodnictwa impulsów nerwowych wzdłuż struktur ośrodkowego i obwodowego układu nerwowego podczas zabiegów chirurgicznych. Rejestracje ruchowych potencjałów wywołanych (MEPs) z mięśni indukowanych impulsami elektrycznymi przezczaszkowo do ośrodków kory ruchowej są szczególnie przydatne podczas operacji chirurgicznych ze zwiększonym ryzykiem jatrogennego uszkodzenia struktur nerwowych.

\section{Cel pracy}

Celem doniesienia jest przedstawienie scenariusza odwracalnego zahamowania przewodnictwa impulsów nerwowych podczas chirurgicznej korekcji deformacji Sprengla wraz z oceną IOM.

\section{Materiał i metody}

Dziewięcioletnia dziewczynka została zoperowana z powodu wrodzonego wysokiego ustawienia łopatki. Operację korekcyjną wykonano metodą Woodwarda z oceną IOM.

\section{Wyniki}

Analizowano parametry amplitud i latencji rejestracji MEPs z mięśni kończyny prawej górnej i zaobserwowano ich spadek oraz wydłużenie o około $20 \%$ podczas końcowej fiksacji łopatki w trakcie operacji Woodwarda. Dzięki tym obserwacjom chirurdzy mogli zapobiec trwałemu uszkodzeniu włókien splotu ramiennego poprzez częściowe uwolnienie zastosowanych szwów. Po operacji i późniejszej rehabilitacji pacjentka powróciła do normalnej aktywności w kończynie górnej prawej. Połączenie elektromiografii i wyników MEPs pomogło w śledzeniu i kontroli przebiegu oraz postępów leczenia.

\section{Wnioski}

Korzyści z IOM polegają na zwiększeniu bezpieczeństwa operacji ortopedycznych i zmniejszeniu liczby jatrogennych powikłań okołooperacyjnych. Ta procedura diagnostyczna jest również mocnym argumentem w obronie przebiegu zabiegów chirurgicznych podczas ewentualnych negocjacji z prawnikiem reprezentującym pacjenta w przypadku wystąpienia powikłań jatrogennych.

Słowa kluczowe: neuromonitoring, zespół Sprengla, metoda Woodwarda

\section{Introduction}

Sprengel's Deformity

A different name for Sprengel's Deformity is the Congenital High Scapula. This condition consists of asymmetrical high scapula position with the accompanying protrusion of its medial edge from the trunk. It is caused by a disruption of the downward movement of the scapula at the end of the first trimester of pregnancy. The reason for this phenomenon is still unknown (Bindoudi et al., 2014). In the 1863 , the first physician reported three cases of severe dislocation of the scapula and described its association with dorsal scoliosis (Horwitz et al., 1908). Most of the patients present difficulties in abducting and functioning of the upper extremity. The significant cosmetic defect of the back is also often present. The choice of treatment method 
depends on the severity of the conditions. In mild cases, physiotherapy treatment and exercises can be used. Unfortunately, surgical correction is often needed. There are three most common types of operation: Green procedure, Woodward method and vertical corrective scapular osteotomy (Sandro et al., 2009; Elzohairy et al., 2019; Mohammad et al., 2020).

\section{Intraoperative neuromonitoring}

Neuromonitoring is a procedure which includes verification of the nerve impulses transmission in the motor and sensory pathways of the spinal cord and the spinal roots (Park and Hyun, 2015). This neurophysiological method is based on using electrical or magnetic stimuli (Huber et al., 2019) and recording evoked potentials from effectors, nerves or sensory cortex with scalp electrodes. For the first time, intraoperative neurophysiological testing was used in the 1930s. That time direct cortical stimulation was performed in order to identify the motor cortex of patients with epilepsy (Penfield et al., 2014). Neuromonitoring is especially useful during the surgical treatment associated with an increased risk of damage to nerve structures. It points out a higher methodologically usability of motor evoked potential recordings (MEPs) than somatosensory evoked potentials (SEPs) (Huber et al., 2019).

\section{Aim \\ Description of the reversible inhibition in pathways transmitting nerve impulses during surgical correction of Sprengel's deformity with the assessment of neuromonitoring (IOM) and to demonstrate the importance of performing pre- and postoperative elec- tromyography (EMG) and MEPs tests.}

\section{Material and methods}

A 9-year-old girl was admitted to the hospital due to Sprengel's deformity. The patient presented difficulties in abducting the right shoulder and functioning of the right upper limb and significant cosmetic defect of the back. Surgeons decided to carry out the surgery with an assessment of intraoperative neurophysiological monitoring.

At the beginning of the surgery the neuromonitoring devices were connected and the impedance of the recording and stimulating electrodes was checked. Stimulation of the right and left side of the cerebral cortex with recordings of the correctness of leads from muscles of the operated right upper extremity did not reveal any abnormalities, comparing the results of amplitudes and latencies measurements in MEPs recorded preoperatively in the Diagnostic Department. Neurophysiological tests of electromyography recordings (EMG) and MEPs recordings were performed in 9-year-old girl. The ISIS Xpress (Inomed Medizintechnik $\mathrm{GmbH}$ ) recorder was used. MEPs were induced via corkscrew anode and cathode implanted subcutaneously at $\mathrm{Cl}$ and C2 ten-twenty system with $150-200 \mathrm{~mA}$ electrical trains of four pulses.

\section{Results}

All parameters of MEPs recordings from muscles of the right upper extremity muscles were close to the physiological limits after the patient was anaesthetized (Figure 1). Then the patient was placed on the operating table in prone position. After transferring the patient all MEP recordings from muscles of the right upper limb were still normal and they became established as the reference (Figure 1A). The first step of the operation was centerline incision. There were no changes in all MEPs potential recordings at this time. After subcutaneous dissection the surgeon released the scapula by transferring the trapezius muscle and the rhomboid minor and major muscles from spinous processes. All MEPs recordings compared to the reference had still the comparable parameters but slightly lower amplitudes, especially in recordings from distal muscles (Figure 1B). The surgeon was informed about this incidence and the last phase of operation was moving down the shoulder blade by $3 \mathrm{~cm}$. After this all MEPs recordings from muscles of the operated 
extremity had still parameters comparable to the reference but with the descrese of $20 \%$ of the initial value. After transferring of the scapula, its final fixation was done by attaching the trapezius and rhomboid muscles to the spinous processes on the lower level. When the drop of amplitude in recordings from distal muscles exceeded $20 \%$ of the reference, the surgeon was informed again and slightly released sutures what prevented the damage to the brachial plexus fibers (Figure $1 C$ ). that intraoperative neuromonitoring was performed, surgeons knew that this situation was not caused by surgery procedures. It turned out that Dessault orthosis was worn too tightly at home. The surgeon decided to stop using orthosis and start activating the muscles of the shoulder girdle with intensive kinesiotherapy. Mobility of the right upper extremity was recovered after one month.
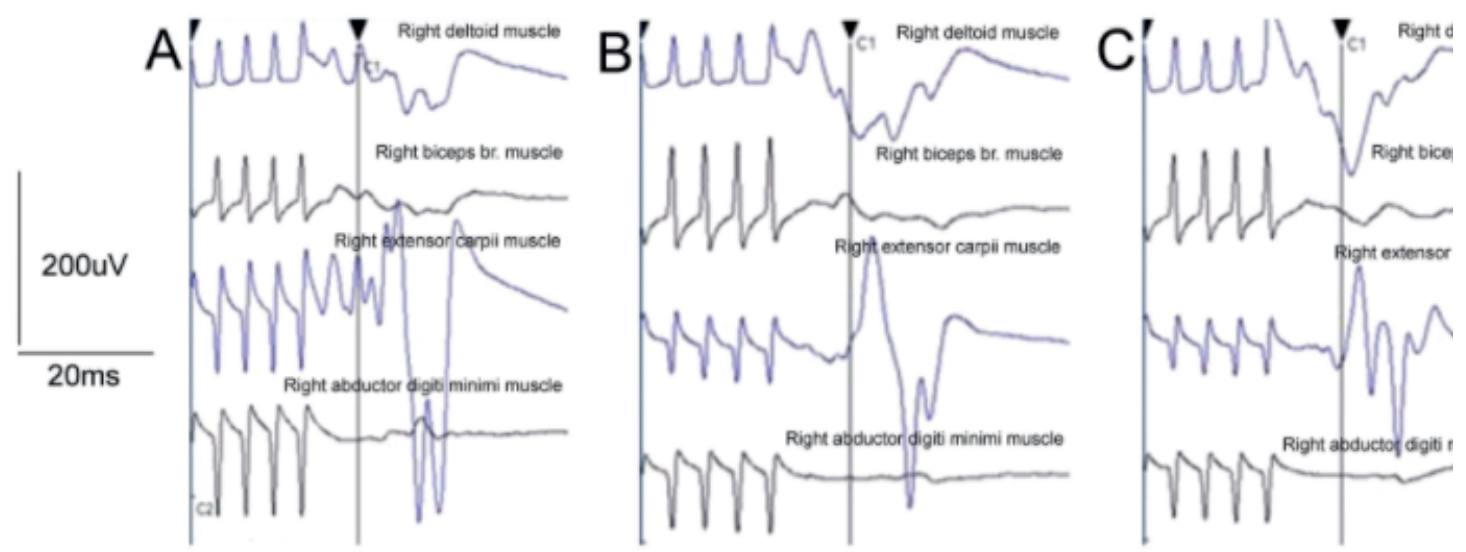

Figure 1. Examples of motor evoked potentials evoked transcranially when trains of electrical pulses were applied to the motor cortex areas and recordings were performed from upper extremity muscles on the right side during the subsequent steps of surgical procedures: A - before surgery, reference recordings; B - during fixation of the scapula with decrease of amplitudes in recordings from mainly distal muscles; $\mathrm{C}$ - after slight releasing of the sutures with subsequent recovery of amplitute parametrs.

The surgery and neuromonitoring were finished. The transmission of the nerve impulses in the right brachial plexus was comparable to the reference ones. After finishing the operation, the patient was awakened. The right extremity clinical testing of muscles strength and range of movements in three planes revealed the slight inalibilty, so results of a clinical and functional examination were consistent with the outcome of neuromonitoring. The patient was discharged home one week after the surgery with the retained mobility of the thumb. Wearing the Dessault type of orthosis was recommended. During the checked-up visit the girl reported slight lack of movement in the operated extremity, C4-C7 electromyography was performed and reduction of amplitude in EMG test and small paresis in the distal part of the right upper limb were observed. For the reason

\section{Discussion}

Recently, neuromonitoring is an increasingly widely used procedure. More and more operations are performed with its support. Somatosensory evoked potentials (SEPs) are used during total shoulder arthroplasty surgery (Atif et. al., 2014). For MEPs tests in shoulder arthroplasty the sensitivity was $100 \%$ and specificity was $98 \%$ estimated. On this basis, it can be concluded that utilization of the real-time diagnostic MEPs data during shoulder arthroplasty what helps surgeons in decision making regarding impending peripheral nerve injuries (Aleem et al., 2018). Axillary nerve mapping is also used during less invasive arthroscopic shoulder stabilization (Esmail et al., 2005). There are also reports which show the utility of neuromonitoring during neurosurgical procedures. SEPs are also used for monitoring surgical craniotomy 
procedures. Patients are positioning supine with their head tilted 30-45 degrees. They develop unilateral upper extremity SEPs changes (Yue Q et al., 2014). MEPs are significant to detect changes in patients with medically refractory temporal lobe epilepsy (TLE) during surgical treatment. It helps with minimizing motor deficits in TLE surgery (Dae et al., 2019). Our case report is in line with the global trends in the use of neuromonitoring during surgery. The operations carry significant risks and the indication to the various treatment modalities is difficult, should be made under monitoring of sensory and motor evoked potentials (Hefti et al., 2002). In the available international literature, the authors of this report did not find a description of the use of MEP in Woodward method.

\section{Conclusions}

Neuromonitoring enabled for a safe surgical correction of Sprengel deformity and can be recommended as a regular procedure during this type of surgery.

\section{REFERENCES}

Aleem A.W., Wilent W.B., Narzikul A.C., et al., (2018), 'Incidence of peripheral nerve injury during shoulder arthroplasty when motor evoked potentials are monitored.' J Clin Monit Comput, 32(5), pp. 897-906. Atif A.M., Nick A., Plumb K., et al., (2014), 'Intraoperative nerve monitoring during total shoulder arthroplasty surgery.' Shoulder Elbow, 6(2), pp. 90-94.

Bindoudi A., Kariki E.P., Vasiliadis K., et al., (2014), 'The rare Sprengel's deformity: our experience with three cases.' Journal of Clinical Imaging Science, 4, p. 55.

Dae L.K., Won G.L., Seung C.H., (2019), 'Clinical Usefulness of Intraoperative MotorEvoked Potential Monitoring during Temporal Lobe Epilepsy Surgery.' J Clin Neurol, 15(3), pp. 285-291.

Elzohairy M.M., Salama A.M. (2019), 'Sprengel's deformity of the shoulder joint treated by Woodward operation.' Eur J Orthop Surg Traumatol, 29(1), pp. 37-45.
Esmail A.N., Getz C.L., Schwartz D.M., et al., (2005), 'Axillary nerve monitoring during arthroscopic shoulder stabilization.' Arthroscopy. 21(6), pp. 665-671.

Hefti F., (2002), 'Kongenitale Fehlbildungen an der Wirbelsäule [Congenital anomalies of the spine].' Orthopade, 31(1), pp. 34-43. Horwitz A.E., (1908), 'Congenital elevation of the scapula-Sprengel's deformity.' J Bone Joint Surg Am, 2(6), pp. 260-311.

Huber J., Wincek A., Kubaszewski Ł., Dąbrowski M., et al., (2019), 'Neurophysiological monitoring performed during surgeries associated with an increased risk of damage to nerve structures.' Praktyczna Ortopedia i Traumatologia, 1, pp. 36-42.

Kadavkolan A.S., Bhatia D.N., Dasgupta B., et al., (2011), 'Sprengel's deformity of the shoulder: Current perspectives in management.' International Journal of Shoulder Surgery, 5(1), pp. 1-8.

Mohammad A.A., Fateme M., Amir F.M., et al., (2020),'Results of surgical treatment for Sprengle's deformity with vertical corrective scapular osteotomy.' Ann Med Surg (Lond), 54, pp. 32-36.

Park J-H., Hyun S-J. (2015), 'Intraoperative neurophysiological monitoring in spinal surgery', World J Clin Cases, 16, 3(9), pp. 765-773. Penfield W., Boldrey E., (2014), 'Somatic motor and sensory representation in the cerebral cortex of man as studied by electrical stimulation.' Brain, 1937(60), pp. 389-443. Sandro S.R., Ruy R.M., et al., (2009), 'Sprengel's deformity: Surgical correction by a Green procedure.' Rev Bras Ortop, 44(3), pp. 208-213. Yue Q., Zhu W., Gu Y., et al., (2014), 'Motor evoked potential monitoring during surgery of middle cerebral artery aneurysms: a cohort study.'World Neurosurg. 82(6), pp. 1091-1099. 